\title{
The changing perception and buying behaviour of women consumer in Urban India
}

\author{
Dr. Sriparna Guha \\ Department of Business Administration Narula Institute of Technology, West Bengal University of Technology, \\ Kolkata, West Bengal,India
}

\begin{abstract}
The working women segment has significantly influenced the modern marketing concept. The objective of this paper is to identify the changing perception and comparison of buying behaviour for working and non-working women in Urban India. It suggests that women due to their multiple roles influence their own and of their family members' buying behaviour. The study also reveals that working women are price, quality and brand conscious and highly influenced by the others in shopping.
\end{abstract}

Key Words: Women, Purchasing behaviour, Perception, Consumer, Urban ,Involvement

\section{Introduction}

Over the years, Indian economy is undergoing through certain changes. Competition has ushered in an altogether new marketing environment in the country. Marketing has become a necessity for survival of business firms. Price, competitiveness, quality assurance and customer service has become vital components of marketing and most business firms are realizing that if they do not have competitive strength, they cannot survive. A business can not succeed by supplying products and services that are not properly designed to serve the needs of the customers. The entire business has to be seen from the point of view of the customer. A company's business therefore, depends on its ability to create and retain its customers. Thus, a company, which wants to enhance it's market share has to think of customers and act customer.

Understanding the buying behaviour of the target market is the essential task of marketing managers in marketing concept. The term consumer behaviour refers to the behaviour that consumers display in searching for, purchasing, using evaluating and disposing of products and services that they expect will satisfy their needs. Consumer behaviour is the most complex aspect of marketing, as it is the most dynamic of all the marketing activities. The consumer preference change rapidly and are affected by multiplicity of factors at a given point of time which are difficult to analyse. To understand the consumer behaviour into consumer motivations, believes, attitudes, learnings, perceptions, emotions and opinion is essential.

\section{Review Of Literature}

Consumer involvement is defined as the consumer's perceived relevance of an object, e.g. product or brand, advertisement or purchase situations based on the inherent needs, values and interests of the persons (Salomon et al., 2004). According to O'Cases (2000), the construct of consumer involvement is important in understanding consumer behaviours related to consumer possessions and there are several broad types of consumer involvement that can be related to the product, to the message or to the perceiver. Zaichkowskey (1986) identified the antecedents of involvement as

a) Person factors

b) Object or stimulus factors

c) Situational factors.

The factors can trigger different types of involvement (product, purchase decision and advertising) than can produce differing results or consequences involvement. Previous researches have shown several ways through which consumers get involved with products and the effect that product involvement has various purchasing and consuming behaviours (Mittal and Lee, 1989; Tigert, Ring and King; 1976).

Women constitute around 48.3 percent of India's population as per the 2001 census and are the precious human resources. Wealth is becoming more concentrated at the top of the income scale. The income of the highest earning households has shown an exponential growth while the gap in household income between top earners and middle earners has widened (Ministry of Labour Statistics, Govrernment of India; 2005). There are 50.69 lakh working women in the organized sector in India, of these, the central government employes about 6 lakh, the state government employ; the state government and bodies under the state government employ about 17 lakhs.

According to Backewell and Mitchell (2003), young female consumers have been influenced by several environmental factors that separate them from older shoppers. Young female have been conditioned into consuming earlier than the previous generations and have been socialized into shopping as a form of leisure. 
They have been developed in an environment that provides more reasons and opportunities to shop as well as additional consumption opportunities such as internet, interest, television, and traditional catalog based shopping. Furthermore, young females are more apt to have become accustomed to media that depict affluent and opulent lifestyle.

According to Zelezny et al., (2000) studies on the women buying behaviour dimensions suggest that females are more pro-environmental while shopping than their male counterparts.

Kindra (1994) defined lifestyle as an external expression of individuals about their needs, opinions and tendencies to participate in the social economic and political life of their countries. This external expression of the customer needs and values is a reflection of what the customer plans to buy and what he/she does not want to buy.

Lifestyle segmentation is very important not only to study women consumer behavior in general but it is also very important in international marketing due to its large impact on the daily purchasing decision made by each individual (Lesser and Hughes 1986, Kucukemiroglu, 2005).

In 1985, Zaichkowsky developed the Personal Involvement Inventory (PII) scale to measure product involvement. Tests of construct validity over three products demonstrated the scores were positively related to perceptions of brand differences, brand preferences, interest in gathering information about the product category, and comparison of product attributes among brands (Zaichkowsky, 1985).

Laurent and Kapferer (1985) concluded that consequences of consumer behavior differ depending on the antecedents of involvement. They developed an involvement profile containing five antecedents of product involvement: a) the perceived importance of a product, b) the perceived importance of negative consequences from a mispurchase, c) the subjective probability of a mispurchase, d) the pleasure value of the product, e) and the perceived sign or symbolic value of the product.

Marketing to women delivers a better return on the marketing dollar through both higher customer acquisition and greater customer retention. Because women are more inclined to long term brand relationships, enhanced loyalty means every marketing dollar invested in acquiring female customers' results in a higher retention rate (Barletta, 2003).

Studies on the women buying behavior dimensions suggest that Females are more pro-environmental while shopping than their male counterparts (Zelezny et al., 2000).

Farhurst et al., (2007) concluded from their study that word of mouth from consumer families and friends can influence decision style, as what and where to buy.

Park and Lennon (2004) concluded that television advertisements can highly influence women buying behaviors along with information received from their friends (Sheers 2007), as females in comparison to males are highly knowledgeable about price and types of stores (Scheers, 2007), and hence this knowledge can influence the retailer management strategies.

The idea that consumers differ in the amount and type of effort they put into shopping is not new to marketing (Katona and Mueller 1955, Newman and Staelin 1972). Such differences are important to marketers because they influence consumers' reactions to marketing strategies. For example, Westbrook and- Fornell (1979) found four distinctive styles of information search among durable goods buyers, ranging from the objective shopper, at one extreme, who makes extensive use of printed sources and in-store shopping guides, to the personal advice seeker, at the other extreme, who relies primarily on personal sources for making buying decisions. Westbrook and Fornell recommend a low-key approach featuring promotional techniques that provide a great deal of factual information for the objective shopper. For the personal ad- vice seeker, however, they recommend a more aggressive, personal, sales-oriented approach. Certainly different strategies would apply to the objective shop- per and the personal advice seeker. Thus, the amount and type of search effort expended by a market segment is an important determinant of the appropriate marketing strategy for that segment.

Kassarjian (1981) has implied a positive relationship between socioeconomic status and purchasing involvement, and in fact describes his "low- low involvement" consumer as being a member of the lower socioeconomic class. This would lead to the assumption that higher income might be associated with higher purchasing involvement. The positive relation- ship found between income and search effort (Clax- ton, Fry, and Portis 1974)

Newman and Staelin(1972) would provide some indirect support for this notion. However, it would seem that the marginal utility of purchasing involvement would be low for high in- come groups, since they can purchase almost anything they want and value their free time more than the money that they could save by wise purchasing. Thus it seems that a curvilinear relationship could be expected between purchasing involvement and income, with moderate levels of income producing the highest levels of purchasing involvement and low and high in- come groups relatively less involved. Education is expected to be positively related to purchasing involvement. Education increases the buyer's ability to use information wisely and therefore his/ her need for information. Or as Westbrook and For nell (1979) have stated: Education was assumed to increase the buyer's 
need for information related to the purchase decision and thereby to increase the value of search and the likelihood of reliance on high value, high cost sources such as Consumer Reports and related buying guides, as well as extensive visits to retail outlets (p.304). Previous research has found education to be related positively to search behavior (Claxton, Fry, and Portis 1974; Newman and Staelin 1972; Westbrook and For- nell 1979); therefore, it is expected to relate positively to purchasing involvement. There is little evidence to suggest that race should be related to purchasing involvement. Although re- search done by Allison (1978) suggests that blacks are more alienated from the marketplace than other groups, it would be speculative to assume that this form of alienation leads to lack of involvement in purchasing. Thus no relationship is assumed to exist between race and purchasing involvement. At this point it should be noted that education, in- come, and stage of family life cycle are all related. The hypotheses below refer to the direct relationship between the demographic variables and purchasing

in- volvement unadjusted for the influence of other variables.

The marketers must carefully monitor the socio-economic environment in order to market and existing product many factors are likely to produce cultural changes within a given society (new technology, population shift, resource shortages, changing values, customs borrowed from other cultures). For example, a major ongoing cultural change in our society is the expanded role options open to woman. Today, most women work outside the home, frequently in careers that once were exclusively men-oriented. The changing nature of culture means that marketers have to consistently reconsider why consumers are now doing what they do, who are the purchasers and the users of their products (males only, females only or both), when they do their shopping, how and where they can be reached by the media and what new product and service needs are emerging. Marketers who monitor cultural changes also often find new opportunities to increase corporate profitability.

\section{Conceptual Framework}

The study tries to capture the changing pattern of buying behaviour of women in urban India. The broad objective of the paper is to identify the changing perception and buying behaviour of working women in contrast to the non working women in Urban India. Specifically, at first, this paper tries to investigate and compare the buying behaviour of women, especially, married and unmarried working women in West Bengal. Secondly, it tries to ascertain which dimension of buying behaviour is prominent among working and non working women. Finally, the study provides comparison of working and non working women's' buying behaviour.

\section{Methedology}

Various aspects of consumer's buying behaviour is an important area of study for researchers around the world. Literatures are gradually developing capturing various aspects and problems of buying behaviour of consumers, possible factors behind the consumption pattern etc. In addition to the existing literature, the present study tries to focus on the aspect from a different angle, where the buying behaviour of employed and unemployed women in urban India has been captured. Both primary and secondary data have been used to conduct the study. Various government reports and proceedings were consulted to collect the published data. On the other hand, a survey has been conducted with the help of a structured questionnaire through direct interview method. The buying behaviour of working and non-working women have been measured through certain indicators, measured in categorical scale. The probable socio-economic variables are measured in both nominal and categorical scale. Buying behaviour of the consumer has been shown through their price consciousness, understanding about the quality of the product, fashion consciousness, brand loyalty, liking of particular store and the convenience.

The target population of the study was working women both from private and public sectors. The study has been conducted in Kolkata and surrounding urban areas. Altogether 196 samples have been selected randomly for the interview purpose.

\section{( TABLE I HERE)}

\section{Result Analysis}

Table II describes the mean values of the variables indicates the buying behaviour of the studied women, both employed and unemployed. The table also tries to specify the average values for married and unmarried sections of the earlier two divisions. In case of price consciousness, there exists less variability in the mean values of married (3.08) and unmarried (3.07) women in employed group. The difference is less in the married (3.02) and unmarried (2.99) section of the unemployed section also, but significant difference can be witnessed between the married women of employed and that of unemployed. Capturing the differences in quality consciousness, it has been found that employed married women are more quality conscious (3.07) than 
the unemployed married women (2.96). It is significantly higher over the employed unmarried (2.91) and even higher than the unemployed unmarried (3.04).

\section{(TABLE II HERE)}

Price consciousness, brand consciousness, quality consciousness has been identified as the significant dimensions of the buying behaviour of women. Income group-wise differences in the values of the respective dimensions have been portrayed in the following section. Following the broad objective, the section tries to capture the differences in the respective dimensions between the employed and unemployed section of women as per various income groups.

Price Consciousness: Price consciousness is one of the important dimension of buying behaviour.On the basis of price consciousness, where only those who are agreed with the statement of price consciousness, has been counted. Table III reveals that most of the employed women are agreed with the price consciousness statements. The unemployed women from the comparatively lower family income group are more price conscious than their employed counterparts and only the highest income group employed women is relatively price conscious.

\section{(TABLE III HERE)}

Brand Consciousness: From Table IV we found that employed women are more brand conscious than the unemployed women, which is true for the entire family income group.

\section{(TABLE IV HERE)}

Table $\mathrm{V}$ reveals that employment status of women is positively related with her average price consciousness. From Table VI, we conclude that employed women, especially, who are engaged in private enterprises, the dimension of price consciousness is negatively correlated, but in case of fashion, it is positively correlated

(Table Vii).

Table VIII shows that employed women are mainly influenced by their family members rather than friends.

\section{Conclusion}

Women, particularly women workforce are vital part of buying behaviour. It has been found that working women are more involved with the purchasing activities. They are more price conscious as compared to the non working married women. It has also been found that working women are more Store loyal than non working married women. In case working women are more quality conscious than non working married women. But non working unmarried women are quality conscious. This study also prevails that there is a significant difference in buying behaviour of working women depending on what type of organization they work. Women are apt to be more involved with purchasing than men, since women have traditionally been the family purchasing agents (Davis 1971, Wilkes 1975) and perceive purchasing as being associated with their role in the family. Woman's role as the family pur- chasing agent, however, seems to be changing, due primarily to the large increase in the number of working women in recent decades.

Therefore, working women has developed as an important segment for the marketers.Therefore, marketers should consider them with utmost importance.

\section{References}

[1]. Bakewell, C. and Mitchell, V. (2003), "Generation Y female consumer decision-making styles". International Journal of Retailand Distribution Management, 31 (2), 95-106. Barletta, M. (2003), "Marketing to women: How to understand, reach, and increase your share of the world's largest market segment." Chicago, IL, Dearborn Trade Publishing. Behling, D. (1999), "Measuring involvement". Perceptual and Motor Skills, 88, 55-64. Census, 2001, India

[2]. Fairhurst, A., Good, L. and Gentry, J. (1989), "Fashion involvement: an instrument validation procedure." Clothing andTextiles Research Journal 7 (3), 10-14. Fenigstein, A., Scheier, M., and Buss A. (1975), "Public and private self-consciousness:

[3]. $\quad$ assessment and theory." Journal ofConsulting and Clinical Psychology, 43 (4), 522-527. Goldsmith, R. (2002), "Some personality traits of frequent clothing buyers". Journal of Fashion Marketing and Management, 6(3), 303-316.

[4]. Goldsmith, R., Moore, M. and Beaudoin, P. (1999), "Fashion innovativeness and self-concept: A replication." Journal of Product and Brand Management, 8 (1), 7-18. Korzaan, M.L. and Boswell, K.T. (2008), "The influence of personality traits and information privacy concerns on behavioral intentions", The journal of computer information system, 48(4), 15-24

[5]. Ministry of Labour Statistics 2005 India, Maspar NV The Retail Weeks, 2007

[6]. O'Cass, A. (2001), "Consumer self-monitoring, materialism and involvement in fashion clothing". Australian Marketing Journal 9 (1), 46-60.

[7]. Solomon, M. and Rabolt, N. (2004), "Consumer Behavior in Fashion." NJ, Prentice Hall. Zaichkowsky, J. (1986), "Conceptualizing involvement." Journal of Advertising, 15 (2), 4- 34

[8]. Tai, H.C. (2005), "Shopping styles of working Chinese females", Journal of Retailing and Consumer Services, 12, 191-203.

[9]. Willaims, T.G. (2002), "Social Class influences on purchase evaluation criteria," Journal of consumer marketing, 19(3), 249-276.

[10]. Yoo, S. (2005), "Design Elements and Consumer Characteristics Relating to Design Preferences of Working Females", International Textile \& Apparel Association, 21(2), 49-62

[11]. Zaichkowsky, J. (1985), "Measuring the involvement construct." Journal of Consumer Research, 12 (3), 341-352.

[12]. Zelezny, L.C., Chua, P.P. and Aldrich, C. (2000), "Elaborating on gender differences in environmentalism," Journal of social issues, 56(3), 443-457 
Summary of Tables:

Table I: Demographic Features of Samples

\begin{tabular}{|l|l|l|l|}
\hline Sl. No. & Description & Employed & Unemployed \\
\hline 1. & Mean age of the respondents (years) & 41.93 & 41.71 \\
\hline 2. & Women employed in private sector (\%) & 38.02 & - \\
\hline 3. & Women employed in public sector (\%) & 61.98 & \\
\hline 4. & Married (\%) & 67.61 & 32.39 \\
\hline 5. & Unmarried (\%) & 46.29 & 53.70 \\
\hline 6. & Bachelor (\%) & 60.23 & 39.77 \\
\hline 7. & Post Graduate and above (\%) & 68.96 & 37.04 \\
\hline 8. & Average family income & 84819.21 & 80522.47 \\
\hline
\end{tabular}

Source: Author's Survey data

Table II: Mean value of the Variables

\begin{tabular}{|l|l|l|l|l|l|}
\hline Sl. No. & Description & Employed & Unemployed & Unmarried \\
\hline & & Married & Unmarried & Married & Un \\
\hline 1. & Price Consciousness & 3.08 & 3.07 & 3.02 & 2.99 \\
\hline 2. & Quality Consciousness & 3.07 & 2.91 & 2.96 & 3.04 \\
\hline 3. & Fashion Consciousness & 3.37 & 3.35 & 3.29 & 3.25 \\
\hline 4. & Brand Consciousness & 2.47 & 2.33 & 2.30 & 2.71 \\
\hline 5. & Loyalty & 3.69 & 3.61 & 3.59 & 3.50 \\
\hline 6. & Convenience & 2.46 & 2.32 & 2.30 & 2.68 \\
\hline 7. & Shopping Influence & 2.55 & 2.52 & 2.53 & 2.73 \\
\hline
\end{tabular}

Source: Author's Survey data

Table III: Income group-wise Differences over Price Consciousness between employed and unemployed

Source: Author's Survey data

\begin{tabular}{|l|l|l|}
\hline Income Group & Employed & Unemployed \\
\hline $30000-45000$ & 5 & 9 \\
\hline $45001-60000$ & 21 & 34 \\
\hline $60001-75000$ & 7 & 11 \\
\hline More than 75000 & 15 & 9 \\
\hline
\end{tabular}

Table IV: Income group-wise Differences over Brand Consciousness between employed and unemployed

\begin{tabular}{|l|l|l|}
\hline Income Group & Employed & Unemployed \\
\hline $30000-45000$ & 16 & 7 \\
\hline $45001-60000$ & 46 & 26 \\
\hline $60001-75000$ & 12 & 9 \\
\hline More than 75000 & 31 & 17 \\
\hline
\end{tabular}

Source: Author's Survey data

Table V: Correlation between Employment Status and Price Consciousness

Correlations

\begin{tabular}{|ll|r|r|}
\hline & & Employment & \multicolumn{1}{c|}{ AVGP } \\
\hline Employment & Pearson Correlation & 1.000 & $.397^{*}$ \\
& Sig. (2-tailed) &. & .000 \\
& $\mathrm{~N}$ & 196 & 196 \\
\hline AVGP & Pearson Correlation & $.397^{\star *}$ & 1.000 \\
& Sig. (2-tailed) & .000 &. \\
& $\mathrm{~N}$ & 196 & 196 \\
\hline
\end{tabular}

${ }^{* *}$. Correlation is signif icant at the 0.01 level (2-tailed).

Table VI: Correlation between Type of Organisation respondent Women Employed and Price Consciousness

Correlations

\begin{tabular}{|ll|r|r|}
\hline & & Type of Orgn & \multicolumn{1}{c|}{ AVGP } \\
\hline Type of Orgn & Pearson Correlation & 1.000 & $-.292^{\star}$ \\
& Sig. (2-tailed) &. & .000 \\
& $\mathrm{~N}$ & 196 & 196 \\
\hline AVGP & Pearson Correlation & $-.292^{\star *}$ & 1.000 \\
& Sig. (2-tailed) & .000 &. \\
& $\mathrm{~N}$ & 196 & 196 \\
\hline
\end{tabular}

${ }^{\star *}$. Correlation is signif icant at the 0.01 level (2-tailed). 
Table VIII: Correlation between Employment Status of Women and Fashion Consciousness

Correlations

\begin{tabular}{|ll|r|r|}
\hline & & Type of Orgn & \multicolumn{1}{c|}{ AVGF } \\
\hline Type of Orgn & Pearson Correlation & 1.000 & $.729^{*}$ \\
& Sig. (2-tailed) &. & .000 \\
& $\mathrm{~N}$ & 196 & 196 \\
\hline AVGF & Pearson Correlation & $.729^{* *}$ & 1.000 \\
& Sig. (2-tailed) & .000 &. \\
& $\mathrm{~N}$ & 196 & 196 \\
\hline
\end{tabular}

${ }^{* *}$. Correlation is signif icant at the 0.01 level (2-tailed).

Table VIIII: Correlation between Employment Status and Shopping Influences

Correlations

\begin{tabular}{|c|c|c|c|c|c|c|}
\hline & & Employment & SPINFL1 & SPINFL2 & SPINFL3 & SPINFL4 \\
\hline \multirow[t]{3}{*}{ Employment } & Pearson Correlation & 1.000 & $-.493^{\star \star}$ & $-.493^{\star *}$ & $.846^{* *}$ & $.846^{*}$ \\
\hline & Sig. (2-tailed) & & .000 & .000 & .000 & .000 \\
\hline & $\mathrm{N}$ & 196 & 196 & 196 & 196 & 196 \\
\hline \multirow[t]{3}{*}{ SPINFL1 } & Pearson Correlation & $-.493^{* *}$ & 1.000 & $1.000^{* *}$ & $-.456^{* *}$ & $-.456^{\star}$ \\
\hline & Sig. (2-tailed) & .000 & & .000 & .000 & .000 \\
\hline & $\mathrm{N}$ & 196 & 196 & 196 & 196 & 196 \\
\hline \multirow[t]{3}{*}{ SPINFL2 } & Pearson Correlation & $-.493^{* *}$ & $1.000^{* *}$ & 1.000 & $-.456^{* *}$ & $-.456^{*}$ \\
\hline & Sig. (2-tailed) & .000 & .000 & & .000 & .000 \\
\hline & $\mathrm{N}$ & 196 & 196 & 196 & 196 & 196 \\
\hline \multirow[t]{3}{*}{ SPINFL3 } & Pearson Correlation & $.846^{\star *}$ & $-.456^{\star \star}$ & $-.456^{\star \star}$ & 1.000 & $1.000^{*}$ \\
\hline & Sig. (2-tailed) & .000 & .000 & .000 & & .000 \\
\hline & $\mathrm{N}$ & 196 & 196 & 196 & 196 & 196 \\
\hline \multirow[t]{3}{*}{ SPINFL4 } & Pearson Correlation & $.846^{* *}$ & $-.456^{\star *}$ & $-.456^{\star \star}$ & $1.000^{* *}$ & 1.000 \\
\hline & Sig. (2-tailed) & .000 & .000 & .000 & .000 & \\
\hline & $\mathrm{N}$ & 196 & 196 & 196 & 196 & 196 \\
\hline
\end{tabular}

**. Correlation is significant at the 0.01 level (2-tailed). 